\title{
Constructing The Status Of Ghanaian Women in Austene's Writings: Pride and Prejudice and Northanger Abbey
}

\author{
Annin, Felicia \\ Faculty of Arts and Social Sciences. Valley View University, Accra: Ghana \\ Osei, Cynthia \\ Department of Liberal Studies. Kumasi Polytechnic, Kumasi: Ghana.
}

\begin{abstract}
The role of women in society is so crucial and inevitable to the extent that they should be given recognition and appreciation to a greater extent. This paper attempts to critically examine the position of women in Jane Austen's novels: Pride and Prejudice and Northanger Abbey andjuxtapose with the position of Ghanaian women. In a recent study, Elleker Boehmer (2005) underlines the usefulness of comparing literary texts by women from postcolonial countries as a way towards greater awareness of the conditions of women in other countries of the world, making possible solutions to problems of women across frontiers while also respecting the differences of the specific circumstances of each woman, and using these women's texts.The study begins with a brief introduction of how women are perceived generally as inferior to men. The historical background of women writers is also traced to buttress the fact that the role of women is so crucial and cannot be down played. Also the views of some feminist writers have also been recorded. The conclusion will explore the role of women in recent times and its impact on the society.
\end{abstract}

Keywords: feminism, male dominance, marginalized, subjugation, counterparts

\section{INTRODUCTION}

Throughout history, the female sex has been looked down upon by their male counterparts. According to the Encarta World English Dictionary (1999), a woman is a female adult. And an adult is supposed to make her own decisions in life, but the female's opinions are most of the time not considered by their male counterparts. Since time immemorial men have always enjoyed the privilege of superiority over women. De Beauvoir (1949) highlights the plight of women: "very often this privilege depends upon inequality of numbers - the majority imposes its rule upon the minority or persecutes it. But women are not a minority, like the American Negroes or the Jews; there are as many women as men on earth." One just wonders the basis of this sex stereotype where women are seen as inferior, and this discrimination should not be based on quantity since human beings are equal. Several women writers have faced a lot of discriminations in the past. In spite of the fact that most women were writing around the C18th, their works were made unpopular because of discriminatory attitudes they faced. Novels of women were not projected unlike their male counterparts. (Bresler, 1994) 
Women have on the whole proved inferior to men but in the act of fiction, they can claim equality to the extent that most of the works they produce are incomparable to that of men. Swinburne (1866) in his poem "Anactoria" declares that "great poets are bisexual, male and female at once". It therefore means that women cannot be devalued, devoiced or demeaned because they are elements of men in women in the same way that some parts of women are placed in men; therefore there is no gain saying that some men are more feminine than masculine, so are some women more masculine than feminine. (cited in Bresler, 1994)

The Ancient Greek culture portrays a man as the head of the family and the master of his wife. In that culture, women, slaves and children are placed on the same pedestal and are not allowed to vote and be voted for. The discrimination extends to even the relationship between the patrician's aristocrats and their women. They held elaborate dinners with parties and wines with girls made to dance and entertain the diners, but their women ate separately; however, their later Empire period allowed decent women to partake in the dinner parties. (Addei and Osei, 2012)

\section{Femininist Theory}

\section{THEORETICAL FRAMEWORK}

What is feminism? It is the belief in securing equal rights and opportunities for women. According to Aristotle, a philosopher and a teacher "A male is by nature superior, and the female inferior, and the one rules and the other ruled". Most women writers in English novels have been devoiced and have been reduced to 'non-significant other' (Bresler, 1994). This is because their novels were not made known to the public. Some of them even wrote under the disguise of men. Those who believe that women's voice should be heard include Mary Wollstonecraft who wrote $A$ Vindication of the Right of Women who ought to stand up to their rights and not allow their male counterpartsto dominate them. She admonishes women to play leading roles in societies.

Simone de Beauvoir, a French writer in her work The Second Sex (1908-1986), declares that the French society and Western societies in general are patriarchal in nature. She believes that the males dominate the society and defines what it means to be human as well as what it means to be female. In her view, since the role of female is defined by men, women are considered as the "Other" in the society. She advises women to break away from their patriarchal bonds since "humanity is male and men define woman not in herself but as a relative to him". Another feminist writer Kate Millet with her publication of Sexual Politics (1969) a new dimension of feminism begins. She argues that one's sex is determined by birth and a person can either be born male or female. She asserts that cultural beliefs established by society seek to establish the role of sexes. Males are portrayed as determining, aggressive, strong etc. while women are meek, passive, humble etc. (cited in Bresler, 1994)

The study seeks to interrogate the status of Ghanaian women and compare it to women presented in Austen's novels. It is also to establish out whether or not the status of women in Ghana differs from the views expressed by the feminists critics stated above.

\section{DISCUSSION}

Austen highlights the theme of love and marriage in her novel Pride and Prejudice which involves the young ladies finding husbands. This issue has deeper overtones about the class character of the early Victorian England where male dominance was the order of the day. The plot is set in Longbourn in Hertfordshire where $\mathrm{Mr}$ and Mrs Bennett live with their five daughters. Mrs Bennett is bent on getting husbands for her daughters and is able to achieve her 
aim as the story enfolds. Jane Austen diligently selects roles for her characters. Female characters in this novel include: Mrs. Bennett, Jane Bennett, Elizabeth Bennett, Charlotte Lucas, Lady Catherine, Lydia Bennett etc.

Northanger Abbey is a story about the protagonist Catherine Morland who leaves her parents and travels with Mr. Allen and Mrs. Allen. Catherine deflates the extreme emotionalism of the Abbey which in a way is a fine defence of the Gothic tradition. She eventually falls in love with Henry Tilney and they get married at the end. Some of the female characters include: Catherine Morland, Isabella Thorpe, Mrs Allen, Mrs Morland and Miss Tilney etc.

\section{Women And Marriage}

Austen in Pride and Prejudice depicts her women as unintelligent people whose only aim in life is in frivolous things. In contrast to the men who are intelligent and serious minded and do not set their minds on superficial things. She portrays Mrs Bennett as a concerned mother who wishes that her girls are married. In her view the only recognition for women in society is to be married; therefore, Mrs Bennett is depicted as fighting for the course of women (feminine stand point) through marriage. This accounts for her interest in getting to know about the new arrivals in their locality. Like most women, Mrs. Bennett sees marriage as the ultimate in life in spite of her mismatch marriage to Mr. Bennett. In contrast to her husband, Mrs. Bennett is presented as "a woman of mean understanding, little information and uncertain temper". (p 1) We only hear of Mrs. Bennett as a married woman whose responsibility is to help her daughters to get married. She does not care if Collins is a fool who hardly deserves to be the husband of Elizabeth. Her only wish is that Elizabeth should marry at all cost.

In Austen's view, Mr. Bennett is an educated man whose interest is in reading and working hard to sustain his family. The same view is expressed by the creation of Amma Darko's character Adade in Faceless, who Darko describes his behaviour as 'the typical Ghanaian fathers' fashion' (p.31) is portrayed as a husband who never comes to the breakfast table without a newspaper in the hand. (p.14)

Austen also portrays some of her women as opportunist and exploitative. Austen's women exploit the system by using all means available to achieve their objectives. This is because these women are not recognized in the society. Charlotte Lucas is happy for being neither beautiful nor rich; she does not hope for more alternative prospects of marriage. Her marriage to Collins is the type of marriage which is purely marriage of convenience based on worldly benefit and practical consideration. Charlotte Lucas takes advantage of the opportunity available to her by involving in this type of marriage. In contrast Elizabeth Bennett disapproves this type of marriage which does not hold any promise of putting happiness in real life companionship for couples. Jane perceives women as the "Other" significant person in marriage. (Bressller, 1994) This is because men are to provide for women, and the women's role is to make the home a comfortable place for men. Even at balls, the power of men is so strong to the extent that they make the choice of their partners to dance with. Consider how marriage is perceived:

In marriage, the man is supposed to provide for the support of women; the women to make the home agreeable to man; he is to purvey, and she is to smile". But in dancing, their duties are exactly changed; the agreeableness, the compliance are expected from him while she furnishes the fan and the lavender water... (p.65) 
In Ghana, there are similar creations of women in most literary writings where women are lured into marriages with the intent of amassing worth.In The Marriage of Anansewaa, Sutherland presents her protagonist, Ananse as an opportunistic person who succeeds in luring the daughter, Anansewaa, into marrying the worthy chief who will be able to take care of the family. Ananse cunningly extorts money from the four chiefs he selects as suitors for the daughter. According to the Storyteller "The process which Ananse is exploiting to select a husband for his daughter, and the same time as a means of getting maintenance for both of them, is full of snares'(p.19). Annin and Abrefa (2014) outline some of the qualities that a prospective husband should possessin the Ghanaian culture; these include potent, hardworking, well respected in the community and of good character. However, the only important trait that will be expected of a woman is submissiveness to the husband.

\section{Women and Gossip}

Austen does not assign major responsibilities to her female characters in Pride and Prejudice. Most of the female characters behave like common place persons who resort to gossips about their neighbours. Mrs. Bennett is worth mentioning in this regard. She gets to know the arrival of new people in the neighbourhood and informs her girls about Darcy and Bingley. When the regiment leaves Meryton, Mrs Bennett feels deeply concerned about the unhappiness of her daughters and foolishly confesses:

Good Heavens! What is to become of us! What are we to do! Would they often exclaim in the bitterness of woe. How can you be smiling so, Lizzy?

I am sure", said she, "I cried for two days together when Colonel Millar's regiment went away. I thought I should have broken my heart. (p.221)

Jane Austen in NorthangerAbbey, portrays Mrs. Allen as a character whose interest is in worldly unimportant things. In contrast Mr. Allen is a serious minded person and also very intelligent. Even at balls, he avoids the company of women and joins the men to talk about politics of the day and compare the accounts of their newspapers while the ladies walk about together to make new friends. She is concerned about one's appearance and therefore dresses nicely and fashionably. She only delights in attending balls and conversing with friends. Her keen interest is in making friends who are of her class at Bath. We read that:

Mrs. Allen was now quite happy, quite satisfied with Bath. She found some acquaintance; had been so lucky, too, as to find them the family of a most worthy old friend; and, as the completion of good fortune, had found those friends by no means so expensively dressed as herself... (p.23)

The character of Mrs. Allen is in contrast with Mrs. Thorpe even though they became friends. In a conversation between them, Mrs. Thorpe talks about her children but Mrs. Allen converses about her gowns (p.23). Austen characterizes Isabella Thorpe as a direct opposite of Catherine. Isabella is gullible and easily deceived. She allows herself to be influenced by Captain Tilney. She is attracted by Captain Tilney's possessions and jilts John Morland. Isabella is an inconsistent character and this feature demeans women.

For my own part', said Isabella, 'my wishes are so moderate that the smallest income of nature would be enough for me. Where people are really attached, poverty itself is wealth grandeur I detest: I would not settle in London for the universe. A cottage in some retired village would be ecstasy... (p. 108) 
Most Ghanaian women are perceived by their male counterparts as gossips and this trait of women have permeated all aspects of their lives. It is not uncommon to witness/find it even among elite class. It is believed that where two or more women are gathered, there is the tendency that they will gossip about others.

\section{Women And Education}

Austen's women are marginalized because they are deprived of access to formal education and this used to be the practice at the time Austen wrote Pride and Prejudice and Northanger Abbey. Some women at that time were educated at home and this includes the author herself. Austen projects people who have received formal education as intelligent. Witness what Austen says about Collins:

Mr. Collins was not a sensible man, and the deficiency of nature had been but little assisted by education or society; the greatest part of his life having been spent under the guidance of an illiterate father: he belonged to one of the universities...( $p .66)$

Jane portrays Catherine Morland in NorthangerAbbey as an unintelligent child who at eight years was often inattentive to what she was taught and occasionally stupid. She was not attentive to what the parents used to teach them.

Her mother was three months in teaching her only to repeat the "Beggar's Petition," and after all, her next sister Sally could say it better than she did."...Writing and accounts she was taught by her father; French by her mother. Her proficiency in either was not remarkable, she shirked her lessons in both whenever she could. (p.2)

Catherine Morland and her sister Sally were educated at home. This is what pertained in English society. One is reminded of the fact that most women novelists had no formal education. According to Feminist critic, Virginia Woolf (1882-1941) in her work, A Room Of One's Own (1919), men have and continue to treat women as inferior. She is of the opinion that Shakespeare's sister was a writer, one of the gifted writers but was devoiced because of her sex. Also much is not heard about her artistic talents because she was not given the same opportunities as her brother who had the chance to be educated. Shakespeare's sister died without any recognition because she wasunknown to the public. (cited in Bresller, 1994) Austen also received education at home. There are similar creations in Amma Darko's Faceless in which she catalogues girls who do not have the opportunity and access to formal education as a result of irresponsible parenting. The main character, a thirteen year old girl, Fofo, Odarley, and Baby T, are street children who have to survive at the mercy of people and also support their parents. Unlike Austen's character Catherine Morland in NorthangerAbbey who was educated at home, the other girls never have access to informal education. Catherine has a family, at least a mother to cater for her, Darko's characters: Fofo, Odarley and Baby T are street children who fend for themselves and their family.

A research conducted by Montgomery et al (2012)reveal 'the socio-cultural implications of physical maturation and menstruation at an individual level, including taboos, myths, puberty rites, household responsibilities, and marital timing. These issues may all have a bearing on girls' school attendance.' This presupposes that some young ladies in Ghana do not attend school because of economic hardship which has informed the Ghanaian government to institute the policy of providing sanitary pads to Ghanaian girls who refuse to go to school when they are in their menstruation period. This created a lot of controversies among the people of Ghana. It therefore goes to confirm that even in recent times, some girls drop out of 
school due to personal issues. Even women who are privileged to access formal education equally face discrimination by their male counterpart at their work places. Currie et.al (2002) in their book, 'Gendered Universities In Globalised Economies' recount the stories of women struggling in excessive 'hegemonic, patriarchal management' of the universities. They also interrogate the 'dominant managerial ethos' which are prevalent in the universities. (28) In spite of the fact that the respondents were from universities in Australia and the United States, some of the stories depicts the Ghanaian situation. As they indicate, 'while the male academic was always supported by a wife who took care of his children, prepared his food, the opposite is true' for the woman. (29) In situations where wives will have the luxury of having their husbands cook, wash and iron for them, it is considered most often as a serious breach of 'accepted cultural practices' (30). Gyamera (2012) posits that any time a Ghanaian woman expresses her opinion about an issue which is perceived as unacceptable in the society, such utterances are described in local parlance as 'mmaasem' which literally means 'women talk'. This in her view has contributed to the marginalization of women in Ghana.

\section{Women and Feminism}

In Pride and Prejudice, Austen presents Elizabeth Bennettas uneducated woman because Elizabeth does not have access to education. She is a responsible young lady who represents the voice of the voiceless. She fights for her rights by being prejudiced against Darcy who initially provokes her. Elizabeth is very assertive and bold in expressing her opinion to Darcy at the ball:

Oh! said she, "I heard you before; but I could not immediately determine what to say in reply. You wanted me, I know, to say "Yes," that you might have the pleasure of despising my taste; but I always delight in overthrowing those kinds of schemes, and cheating a person of their premeditated contempt. I have therefore made up my mind to tell you, that I do not want to dance a reel at all- and now despise me if you dare. (p.48)

Elizabeth Bennett has control over her thoughts and is able to decide for herself. In spite of the pressure her mother gives her about the contracted marriage between Collins and her, she refuses to succumb to Collin'sploy. Consider how she refuses Mr. Collins:

Really, Mr. Collins cried Elizabeth with some warmth, you puzzle me exceedingly. If I have what hitherto said can appear to you in the form of encouragement, I know not how to express my refusal in such a way as may convince you of being one (p.106)

She is also seen as a good counsellor who admonishes her sister Jane to take a decision on Bingley, a man whose sisters and friends are all wishing him to marry elsewhere:

You must decide for yourself", and Elizabeth, "and if upon mature deliberation, you find the misery of disobliging his two sisters is more than equivalent to the happiness of being his wife, I advise you by all means to refuse him. (p.117)

Even after Darcy revises his opinion about Elizabeth and gets more attracted towards her because of her beautiful eyes, Elizabeth'sprejudice increases against Darcy on hearing the bad treatment Darcy gives Wickham. Elizabeth's prejudice again turns into hatred when she holds Darcy responsible for separating her sister Jane and Bingley, the proposed lover. Witness what she says about Mr. Bingley: 
I am astonished at his intimacy with Mr. Bingley! How can Mr. Bingley, who seems good humour itself, and is, Ireally believe, truly amiable, be in friendship with such a man? How can they suit each other?... (p.79)

Significantly, Austen portrays some of her female characters as easily influenced and attracted by unimportant things. Elizabeth Bennett was not only prejudiced about Darcy because of his attitude towards her, but also she allowed herself to be manipulated by Wickham. She could not decipher between the lies told by Wickham and investigate about Darcy but gullibly accepts the deceit Wickham tells her. Elizabeth who prides herself on the sadness of her judgement now realizes how her prejudices has overtaken her vision and led her to misjudge Darcy and Wickham.

Austen presentssome of the women are persistent, determined and focused, and they are really able to fight for their rights in a very subtle way. One of such characters in Pride and Prejudice is Jane Bennett. She is an unassuming intelligent girl who comports herself throughout the story. Jane is not easily swayed by the Bingley's inconsistent life style, but able to fight for what really belongs to her. This attitude is reflected in her relationship with Bingley. She does not side with Elizabeth on hearing about Darcy's deeds:

Laugh as much as you choose, but you will not laugh me out of my opinion. My dearest Lizzy, do but consider in what disgraceful light it places Mr. Darcy, to be treating his father's favourite in such a manner... No man of common humanity, no man who had any value for his character, could be capable of that... (p.82)

Lady Catherineis equally conceited and a powerful lady who is able to control both men and women. Jane invests Lady Catherine with the feminist spirit. She dictates to people around her and her orders are followed to the latter. Her relationship with Collins was purely based on respect. She is a large woman with strong distinct features and an authoritarian who treats both men and women as inferiors. She is described as 'not rendered formidable by silence' but uses so 'authoritative a tone' in her speech.

Women are presented as inquisitive and gossips. On the contrary, it is a positive attitude in the sense that a society without information will certainly collapse and the role of such women is very significant

Austen also presents Catherine Morland in NorthangerAbbey as a matured girl who is strong and fearless and able to stand up to the task ahead of her. Catherine is not easily influenced by other characters and does not budge in her search for the truth about the Gothic tradition. She represents the feminist voice in the novel. Catherine does not allow her conviction to be trampled upon. Catherine is uncompromising because she does not allow either Isabella or James to influence her views. Witness how she is characterized:

I did not think you had been so obstinate, Catherine,' said James; 'you were not used to be so hard to persuade; you once were the kindest, best tempered of my sisters'( $p$ 87). 'Then I will go after them', said Catherine; 'wherever they are, I will go after them. It does not signify talking. If I could not be persuaded into doing what I thought wrong, I never will be tricked into it'. And with these words she broke away and hurried off. Thorpe would have darted after her, but Morland withheld him'. 'Let her go, let her go, if she will go. She is as obstinate as--- (p.98) 
Mrs. Morlandis an ideal woman who is able to affect her children's life style. Austen depicts her as a good woman who wishes to see her children in anything they ought to be. She however devotes much time for children leaving the older ones to take care of themselves. She introduces and encourages Catherine to read because she also reads a lot of novels. This is the mark of an enlightened woman who knows what she is about. Catherine's conversation with Isabella reveals that:

it is so odd to me, that you should never have read Udolpho before; but I suppose Mrs. Morland objects to novels.

No she does not. She very often reads Sir Charles Grandison herself; but new books do not fall in our way. (p.28)

Mrs. Marland cautions her daughter against noble men and baronets who delight in forcing young ladies to the remote farm house. In her parting words to Catherine she reiterates the following points:

I beg Catherine, you will always wrap yourself up very warm about the throat when you come from the Room at night; and I wish you would try to keep some account of the money you spend; I will give you this little book on purpose. (p.6)

Austen portrays Isabella Thorpe in Northanger Abbey as a conscientious character who is conscious of the fact that some men take women for granted and intends to fight for her right. Witness what she says about men:

...The men think us incapable of real friendship, you know, and I am determined to show them the difference. Now, if I were to hear anybody speak slightingly of you, I should fire up in a moment: but that is not at all likely, for you are just the kind of girl to be a great favourite with the men. (p.27)

\section{CONCLUSION}

From the foregoing, it can be deduced that women played significant roles in the English novels though they were not very much recognized in their society. While some women were intelligent, others were only interested in frivolous things because they did not have equal access to education which the men had. Most African writers present the African woman as week and feeble. In the olden times, the position of females was the kitchen. Most girls were not given formal education unlike the males. The African society has stereotyped women to an extent that women have been given menial roles to play in the society, which most men will not associate themselves with.

Ghanaian culture for instance endorses polygamous marriage for men; however the women are restricted to marrying only one and those who flout such rule are classified as prostitutes. Even in recent times where both men and women are both career-oriented and share responsibilities in a home, the women still take care of the home. Women are portrayed as inquisitive and gossips. On the contrary, it is a positive attitude in the sense that a society without information will certainly collapse and the role of such women is very significant and should not $\mathrm{b}$ taken for granted.

\section{References}

Addei, C. \& Osei, C. E. (2012) The Position of Women in Greek and Africaan Culture: A Study of Aristophanes' Lysistrata and Rotimi's our Husband has Gone Mad Again, The Social Sciences, Vol.7 Issue. 4 pp.539-544. 
Annin, F., \& Osei, C. (2015). Constructing the Status of Ghanian Women in Austene's Writing: Pride and Prejudice and Northanger Abbey . Advances in Social Sciences Research Journal, 2(1), 34-42.

Annin, F. \& Abrefa, A. A.(2014) Representations Of Ghanaian Tradition In Sutherland's The Marriage Of Anansewaa And Fiawoo's The Fifth Landing Stage International Journal of Scientific \& Technology Research, VOL 1, ISSUE 1pp.89-94

3. Arthur, C. R. (2001), A History Of English Literature, New Delhi, UBS Publishers' Distributors Pvt. Ltd.

4. Austen, J. (1818), Northanger Abbey, London, Penguin Books Ltd,

5. Austen, J. (2012), Pride and Prejudice (Revised Edition), New Delhi, UBS Publishers' Distributors Pvt. Ltd.

6. Bressler C. E. (2003), Literary Criticism - An Introduction to Theory and Practice, Upper Saddle River, New Jersey, Prentice Hall.

7. Currie, J. Thiele, B., Harris, P. (2002) Gendered universities in globalised economies. USA: Lexinton, Books.

8. Darko, A. (2010), Faceless, Accra, Sub-Saharan Publishers.

Encartha World English Dictionary (1999) London: Bloombury Publishing Plc.

Gyamera, G.O. (2012) Positions and Ranks of Female Academics in The Public

Universities in Ghana: Realities and Implications, University of Roehampton (UNITED KINGDOM) gyamerag@roehampton.ac.uk

Montgomery, P., Ryus, C. R., Dolan, C. S., Dopson, S. \& Scott, L. M. (2012). Sanitary Pad Interventions for Girls' Education in Ghana: A Pilot Study. 10.1371/journal.pone.0048274

10. Sutherland, E.T. (1975) The Marriage of Anansewa, Accra: Sedco Publishing Ltd. 